\title{
"THE EFFECT OF MIXED GAMIFICATION AND ACHIEVEMENT MOTIVATION ON CONCEPT COMPREHENSION AND CREATIVE THINKING SKILLS IN LEARNING SCIENCE."
}

\author{
Bilqis Firyal Nabilah ${ }^{1 *}$, I Nyoman Sudana Degeng' ${ }^{2}$, Waras Kamdi ${ }^{3}$, Sulton $^{4}$
}

1,2,3,4 Universitas Negeri Malang, Indonesia Corresponding Email: cahayafiryal@gmail.com

\begin{abstract}
:
This research is motivated by the poor comprehension and creativity of elementary school students in science lessons. This study aimed to determine gamification's effect on improving learning outcomes in concept comprehension and creative thinking skills in students studying science. Achievement motivation is suspected of being involved as a variable that interacts with gamification in improving learning outcomes. The data analysis technique used the Multivariate Analysis test. The research subjects were 73 students in the control class and the experimental class. This research is a quasi-experimental research, with a $2 \times 2$ factorial, and pretest-posttest non-equivalent control group design. The experimental class uses mixed gamification, while the control class uses content gamification. The difference between the two lies in the gamification elements used. The study results showed that 1) there was no significant difference in the learning outcomes of conceptual comprehension between groups of students who used mixed gamification and content gamification; 2) there was no significant difference in the learning outcomes of conceptual comprehension between groups of students who have high achievement motivation and low achievement motivation; 3 ) there was no interaction between gamification (mixed gamification and content gamification) and achievement motivation on learning outcomes comprehension the concept; 4) there was no significant difference in the learning outcomes of creative thinking between groups of students who use mixed gamification and content gamification; 5) there was no significant difference in the learning outcomes of creative thinking between groups of students who have high achievement motivation and low achievement motivation; 6) there was no interaction between gamification (mixed gamification and content gamification) and achievement motivation on learning outcomes to think creatively. Achievement motivation is not the only factor that affects the learning outcomes of concept comprehension and creative thinking. Future research is important to consider the different moderator variables from achievement motivation and other gamification elements.
\end{abstract}

Keywords

Gamification, Achievement-Motivation, Concept-Comprehension, Creative Thinking Skill, Science Learning. Article Received: 18 October 2020, Revised: 3 November 2020, Accepted: 24 December 2020

\section{INTRODUCTION}

Based on Indonesia Central Bureau of Statistics data, the Alpha generation in Indonesia currently numbers 45.93 million people [1] and will continue to grow until 2025. In education, the oldest Alpha generation in Indonesia is currently studying in grade 3 of elementary school. The Alpha generation has a unique way of thinking and learning because it is influenced by technology [2]. Different generations have different characteristics and attitudes in learning [3]. Children are increasingly demanding more enjoyable, more interactive, and responsive play experiences [4]. The Alpha generation spends more time communicating online than face-to-face communication [5]. Knowledge of generations can help make the learning process more effective and efficient [6].
The learning problem that is being faced by the alpha generation of Indonesia is that they are experiencing severe problems in the field of quality science education. Science education has a significant role in preparing a generation to build a nation in the future [7]. The latest PISA (Programme for International Student Assessment) stated that the science ability of Indonesian students in 2018 at the international level was low. As many as $7 \%$ of students succeeded at level-5 and 6 , only $7 \%$ of them could apply their science knowledge creatively to various situations. There are $78 \%$ of students who succeeded at level-2, which indicates that they can use their knowledge to identify simple cases even though the conclusions are not all correct. Furthermore, $89 \%$ of Indonesian students reported 
feeling capable of solving problems, but $59 \%$ felt afraid if their answers were wrong. Meanwhile, $91 \%$ of Indonesian students reported feeling happy at school [8].

The Ministry of Education and Culture of Indonesia continues to make policies to improve education quality, starting from enhancing the curriculum, funding assistance for every school throughout Indonesia, improving teachers' quality, and many others [9]. Meanwhile, in each classroom, teachers continue to improve the quality of learning due to having attended training provided by the government nationally. However, the average science learning outcomes are still deficient and unsatisfactory [8]. One of the factors reported to influence their poor learning outcomes is low learning motivation [10]-[14].

Generational characters have changed, so learning must also change [15]. With the Alpha generation characteristics different from the previous generation, teachers should modify the learning process. Schools and universities must not turn a blind eye to the learning needs of this generation. However, the fact is that most primary schools in Indonesia still use the teacher-centred learning format without considering the needs and learning characteristics of the alpha generation, which tends to be student-centred. Learning models, strategies, media, and materials can be accommodated the learning needs of Alpha generations.

One of the latest media that can attract learning attention and generate students' achievement motivation is gamification because today's students are a generation with high interactivity with a technology called the digital native generation [16]. Gamification is defined as a process of increasing motivation, creating pleasant experiences, and learning outcomes through game mechanisms [17]. Interest in gamification is also reflected in the world of education. An increasing number of successful educational startups add gamification to their services as a core activity, such as Code Academy, Khan Academy, Socrates, and Duolingo.

Gamification does not mean making games. Gamification uses game mechanics, aesthetics, and game thinking to engage humans, motivate action, and solve problems in the learning process. The results showed that gamification could make the learning process more enjoyable and increase participation. Gamification helps students get the motivation to learn, and because of positive feedback, they keep going and become more interested and stimulated to learn [18]. Gamification in education has significant support among researchers and educators because games can boost productivity and creativity [19]. The main value of gamification is high learning participation, collaboration, and learning to be more fun. Elements in gamification can be used to increase intrinsic motivation [20]. Gamification has the same psychological experience as playing games [21].

There are two types of gamification, namely structural gamification and content gamification [22]. The two types can be standalone or be used simultaneously. When used together, it is called mixed gamification.

Structural gamification uses game elements to encourage students to learn the material without changing the material itself. The material does not become like a game; only the structures around the material are given gamification elements. This type of gamification's primary focus is to motivate learners to learn the material and engage them in the learning process through rewards. An example is a student who gets points in a lesson when he finishes watching a video or completes an assignment. The assignments or videos have no game element associated with them other than the fact that the learner receives points when he or she finishes watching the video or completes the task.

The most common elements in this type of structural gamification are points, badges, leaderboards or levels. There is also a social element where students can share their achievements with other students and share what they have achieved. While it is possible to add various gamification elements to structural gamification, it still does not turn the material into 
a game-like appearance.Gamification systems that assign students the task of earning badges and displaying leaderboards are elements often used in gamification in class. The use of badge and leaderboard elements is useful for tracking progress, increasing student engagement, and facilitating competition [23].

Content gamification is gamification that applies game elements and game thinking to transform content to make it more like a game. For example, adding a story element or starting a lesson with a challenge. Adding these elements makes the content more game-like. Content gamification elements are the story, challenge, curiosity, character, interactivity, feedback, and freedom to fail. Content gamification only provides context or activities used in the game and adds it to the content/material being taught.

People do not play games only for points; they play for mastery, to overcome challenges, and socialize with others [24]. The most effective gamification efforts involve more than collecting points and badges, but also contain elements of storytelling, challenges, and ongoing feedback as well as high levels of interactivity. The interactivity is the most interesting element and has a significant effect on the game. Game mechanisms can increase interactivity, reward, and motivation [25]. Several game mechanisms can motivate learners who naturally require recognition[26].

Concerning the role of motivation during learning, many have shown that motivation can influence what, when, and how we learn [27]. Achievement motivation was first introduced by Harvard psychologist Henry Murray in 1938 and systematically formalized in the 1950 s by David McClelland and John Atkinson [28]. Achievement motivation is defined as the desire to do something well, achieve something difficult, overcome problems, achieve high standards, excel, and surpass others [29]. Achievement motivation is oriented towards an expectation approach to success or is oriented towards avoidance/fear of failure [30].

The categories related to academic achievement motivation are persistence, overcoming problems, maintaining high standards, solving difficult things, positively competing, and having the courage to take the risk of failure [31]. Besides, individuals who have high achievement motivation are attracted to concrete and feedback about their routine progress [30]. They seek reliable, measurable, and factual feedback because it can support them to improve their performance.

Science is the studies about how the formation of an individual, social, until the universe formed by using a series of scientifically controlled observations and experiments [7]. Science specifically tries to provide answers and explain a phenomenon that does not usually occur in nature.In learning science concepts, students need thinking skills. Thinking skills are divided into low-level thinking skills and higher-order thinking skills.

In Bloom's taxonomy of learning, concept comprehension is lower-order thinking skills at the second cognitive level (C2). Concept comprehension is needed in studying science because understanding the cognitive system is responsible for translating knowledge into a form suitable for storage in long-term memory (Marzano and Kendall, 2007). When students have understood a basic concept, it will be easier for students to apply, analyze, evaluate, and create an idea so that it leads to mastery of the concept. Concept comprehension is the main foundation in self-development in using various methods to create new and valuable ideas and explain, revise, analyze, and evaluate one's thoughts to enhance and maximize creativity [33]. Students comprehension of concepts can be identified through several indicators: the ability to explain, classify, characterize, detail, compare, change, suggest, discuss, and conclude [34]. Comprehension concepts are closely related to students' ability to solve problems [35].

The main purpose of science education is to teach basic knowledge and use higher-order thinking skills such as creative thinking skills [36]. Teachers cannot merely transfer knowledge to students because students must also be involved in the learning process to build their knowledge and comprehension [37]. Creativity involves thinking aimed at producing relatively new and 
exciting ideas or products [38]. Creative thinking skills are needed so that students can create, manifest into new forms, produce through imaginative skills create, or realize something new [39]. Developing students creative thinking skills means allowing students to study material more flexibly to find and solve problems and communicate ideas [40]. Students' creative thinking skills can be identified through several aspects, namely curiosity, originality, fluency, and elaboration [39].

Several studies have reported the success of gamification. The meta-analysis of gamification journals published between 2014 and 2018 shows that gamification positively affects children's learning outcomes, including mathematics, language, social, and health [41]. Chen found that gamification in role-playing lessons can increase student motivation and creativity [13]. Gamification can be an excellent solution to help solve student engagement problems and class participation [42]. Gamification for learning and education can improve learning achievement [43]-[46], improve higher-order thinking skills [43], student retention of the material being taught [44], and performance tests [45]. However, no research has been found examining the effect of gamification and achievement motivation on concept comprehension and creative thinking abilities for elementary school students in science learning.

\section{Hypothesis:}

This study consists of six hypotheses:

H1. There was a significant difference in students' concept comprehension who taught using mixed gamification compared to content gamification.

$\mathrm{H} 2$. There was a significant difference in students' concept comprehension who have high and low achievement motivation.

H3. There was a significant interaction between gamification and student achievement motivation on learning outcomes concept comprehension.

H4. There was a significant difference in students creative thinking skills who taught by using mixed gamification compared to content gamification.
H5. There was a significant difference in students' creative thinking skills who have high and low achievement motivation.

H6. There was a significant interaction between gamification and student achievement motivation for creative thinking skills.

\section{MATERIALS AND METHODS: 2.1. Research Design and Samples}

This research is quasi-experimental-research design Nonequivalent Control Group Design. Based on the variables studied, the factorial design was $2 \times 2$. The subjects of this study were 60 students of grade 3 elementary school in Batu City, Indonesia. In the study, researchers used two classes, namely the experimental class and the control class. The number of students in each category is 38 and 35 students.

\begin{tabular}{c|l|l}
$\begin{array}{c}\text { Table 1. Factorial Design } 2 \times 2 \\
\text { Achievement }\end{array}$ & Mixed & Content \\
Motivation & Gamification & Gamification \\
& (Experimental & (Control \\
& Class) & Class) \\
& $\mathrm{X}^{1}$ & $\mathrm{X}^{2}$ \\
\hline High $\mathrm{Y}^{1}$ & $\mathrm{X}^{1} \mathrm{Y}^{1}$ & $\mathrm{X}^{2} \mathrm{Y}^{1}$ \\
Low $\mathrm{Y}^{2}$ & $\mathrm{X}^{1} \mathrm{Y}^{2}$ & $\mathrm{X}^{2} \mathrm{Y}^{2}$ \\
\hline
\end{tabular}

The steps for implementing gamification learning consist of 1) advance organizer presentations, 2) presenting assignments or learning materials, and 3) strengthening cognitive structures. The experimental class uses mixed gamification elements such as badges, leader boards, points, and Kahoot. The control class uses content gamification elements in the form of Kahoot.

The outline of the research design is illustrated in Figure 1. 


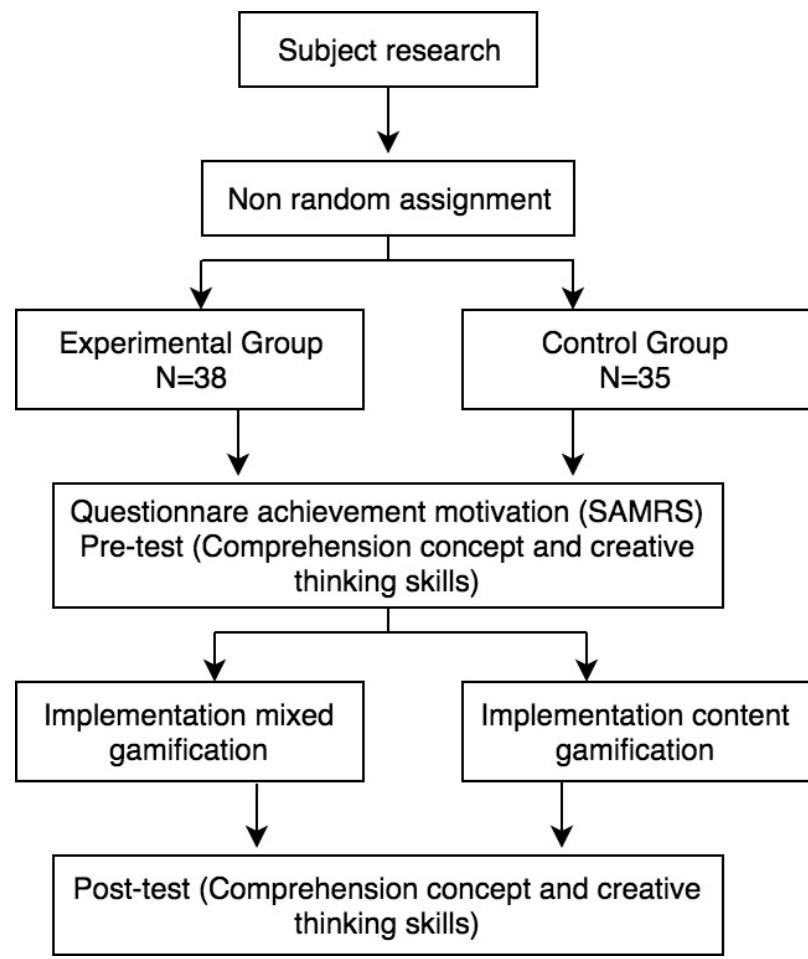

Figure 1. Outline of Research Design

\subsection{Data Collection Tools and Analysis}

The achievement motivation measurement uses the School Achievement Motivation Rating Scale (SAMRS) questionnaire developed by LianHwang Chiu [31] on a range of 1-5. The questionnaire consisted of 15 items, with each item describing an aspect related to academic achievement motivation. Motivation can be assessed by direct observation, assessment by others, and self-reports [27]-[72]. In this study, students did self-reports. Self-reports capture people's judgments and statements about themselves. Self-reports are the most common way that researchers assess motivation [47].

The instrument of concept comprehension learning outcomes consists of 15 multiple choice items with scale 0 and 1 . A creative thinking instrument adapted from Laura Greenstein's [39] on a range scale 1-4. Researchers took five indicators on creative thinking skills: curiosity, fluency in finding ideas, originality of ideas, developing ideas, and variations of ideas. The concept comprehension test and creative thinking skills were given two times, by the pre-test and post-test.
The research data were analyzed using multivariate analysis of variance (MANOVA). MANOVA is a statistical method for determining whether independent groups differ on more than one dependent variable [48]. The statistical analysis included the normality test, homogeneity test, multivariate test, and test of between-subjects effects.

\subsection{Implementation of Gamification}

The use of gamification in learning requires a learning strategy or model because gamification is the learning media. Learning media cannot be used or stand-alone without using a learning strategy or model. The learning model used in this study is an advance organizer. Research conducted by Susilowati [49] shows that using an advance organizer can improve learning outcomes in concepts comprehension compared to learning, not using an advance organizer.

The science topic that is studied in this research is changing in the form of objects. Worksheets were given to both groups, both the experimental group and the control group. The problems given to both classes are the same. The implementation of mixed gamification and content gamification uses the advance organizer learning model (Models of teaching). During learning in the experimental class, the teacher as a facilitator motivates students to collect badges, points, and win the Kahoot quiz. In the control class, the teacher motivates students to win the Kahoot quiz.

\section{RESULT AND DISCUSSION:}

Using Shapiro-Wilk in the experimental class using mixed gamification, the normality test results obtained a value of 0.127 on concept comprehension and 0.597 on creative thinking skills. The control class that uses content gamification scores 0.312 on concept comprehension and 0.471 on creative thinking skills. Overall, normality test data has been normally distributed because the p-value acquisition is greater than the standard value $(p>$ $0.05)$. Using the Levene test, the homogeneity test 
results obtained data of 0.714 on concept comprehension and 0.709 on creative thinking. Overall, data homogeneity has fulfilled the assumption that the data comes from the same variant because $\mathrm{p}$-value $>0.05$.

Hypothesis testing is done using; 1) Multivariate analysis to test gamifications affects learning outcomes of concept comprehension and creative thinking skills together. This test aims to assess the significance of the difference in scores between the mixed gamification group on the variables of concept comprehension and creative thinking skills due to the primary influence and interactions between the independent variables.

The results showed that each learning media's main effect was to obtain a probability value that was smaller than the standard criteria (sig) $0.001<0.005$, so it was concluded that the gamification media in the two classes affected improving learning outcomes simultaneously. The achievement motivation results are $0.790>0.005$, so it can be concluded that achievement motivation does not affect comprehension concepts and creative thinking skills.

After knowing each independent variable's influence on the dependent variable, 2) Hypothesis testing using a Test of BetweenSubjects Effects to determine the effect between variables by testing the comparison between the estimated average score and knowing the interaction between variables is presented in Table 2.

\begin{tabular}{|c|c|c|c|c|c|c|}
\hline Source & Dependent Variable & $\begin{array}{l}\text { Type III Sum } \\
\text { of Squares }\end{array}$ & df & $\begin{array}{l}\text { Mean } \\
\text { Square }\end{array}$ & $\mathrm{F}$ & Sig. \\
\hline \multirow[t]{2}{*}{$\begin{array}{l}\text { Corrected } \\
\text { Model }\end{array}$} & Creative_Thinking & $2933.115^{\mathrm{a}}$ & 3 & 977.705 & 5.201 & $\begin{array}{r}.00 \\
3\end{array}$ \\
\hline & $\begin{array}{l}\text { Concept_Comprehen } \\
\text { sion }\end{array}$ & $193.175^{\mathrm{b}}$ & 3 & 64.392 & .531 & $\begin{array}{r}.66 \\
2\end{array}$ \\
\hline \multirow[t]{4}{*}{ Intercept } & Creative_Thinking & 1044958.897 & 1 & 1044958.8 & 5558.91 & .00 \\
\hline & & & & & & \\
\hline & Concept_Comprehen & 446556.948 & 1 & 446556.94 & 3683.49 & .00 \\
\hline & sion & & & 8 & 9 & 0 \\
\hline \multirow[t]{2}{*}{ Gamification } & Creative_Thinking & 2849.563 & 1 & 2849.563 & 15.159 & .00 \\
\hline & $\begin{array}{l}\text { Concept_Comprehen } \\
\text { sion }\end{array}$ & 63.151 & 1 & 63.151 & .521 & .47 \\
\hline \multirow[t]{3}{*}{ Motivasi } & Creative_Thinking & 81637 & 1 & 81637 & 434 & .51 \\
\hline & Concept Comprehen & & & & & .82 \\
\hline & sion & 6.182 & 1 & 6.182 & .051 & 2 \\
\hline \multirow{3}{*}{$\begin{array}{l}\text { Gamifikasi * } \\
\text { Motivasi }\end{array}$} & Creative_Thinking & 35.056 & 1 & 35.056 & .186 & .66 \\
\hline & Concept Comprehen & & & & & 35 \\
\hline & sion & 103.619 & 1 & 103.619 & .855 & 8 \\
\hline \multirow[t]{2}{*}{ Error } & Creative_Thinking & 12970.556 & 69 & 187.979 & & \\
\hline & $\begin{array}{l}\text { Concept_Comprehen } \\
\text { sion }\end{array}$ & 8364.990 & 69 & 121.232 & & \\
\hline \multirow[t]{2}{*}{ Total } & Creative_Thinking & 1095128.000 & 73 & & & \\
\hline & $\begin{array}{l}\text { Concept_Comprehen } \\
\text { sion }\end{array}$ & 470334.000 & 73 & & & \\
\hline \multirow[t]{2}{*}{ Corrected Total } & Creative_Thinking & 15903.671 & 72 & & & \\
\hline & $\begin{array}{l}\text { Concept_Comprehen } \\
\text { sion }\end{array}$ & 8558.164 & 72 & & & \\
\hline
\end{tabular}

a. $\mathrm{R}$ Squared $=.184$ (Adjusted R Squared $=.149)$

b. $\mathrm{R}$ Squared $=.023$ (Adjusted R Squared $=-.020$ )

Table 2. Hypothesis Test Results

$\boldsymbol{R}$-Square - This is the proportion of variability in explained the dependent variable (useful) that can be 
by the model. It is the ratio of the model sum of squares to the total sum of squares.

Source - This is the source of the variability in the specified dependent variable.

Dependent Variable - This is the variable observed for the effect of treatment on MANOVA.

Type III SS - This is a type of sum-of-squares calculation. SS gives the sum of squares that would be obtained for each variable if it were entered last into the model. That is, the effect of each variable is evaluated after all other factors have been accounted for.

$\boldsymbol{d} \boldsymbol{f}$ - This is the number of degrees of freedom in the model.

Mean Square - This is the sum of squares divided

\subsection{Hypothesis Testing 1}

The data results from table 2 showed no significant difference in the comprehension concepts between groups of students who use mixed gamification and content gamification because the value obtained is $0.473>0.05$. The gain score data analysis results showed an increase in the value from pre-test to post-test by $9 \%$ in classes using mixed gamification and $13 \%$ in classes using content gamification. From these data, it can be concluded that both mixed gamification and content gamification improve learning outcomes in concept comprehension. This result follows Goethe (2019) that both mixed gamification and content gamification can improve concept comprehension because gamification elements and mechanisms can be used in the learning process to achieve learning objectives, increase student involvement, and create effective learning process. One of the factors influencing success in learning is student involvement [51].

There are six dimensions in the field of science, namely four cognitive dimensions and two affective dimensions. The six dimensions are, 1) knowing, using, and interpreting scientific explanations; 2) produce and evaluate scientific evidence and explanations; 3) understand the nature and development of science; and 4) participate productively in scientific discourse and by the degrees of freedom.

$\boldsymbol{F}$ - This is the approximate $F$ statistic for the given effect and test statistic.

Sig. - This is the p-value associated with the F statistic and the hypothesis and error degrees of freedom of a given effect and test statistic.The null hypothesis that a given predictor has no effect on either of the outcomes is evaluated with regard to this p-value. For a given alpha level, if the p-value is less than alpha, the null hypothesis is rejected and accepted $H_{1}$. If not, then we fail to reject the null hypothesis.

Partial Eta Squared -The ratio of variance associated with an effect, plus that effect and its associated error variances.

practice; 5) involvement and motivation of students to learn by giving them experiences in the physical world; and 6) placing students in a scientist's position that allows them to practice the scientific process [52]. In line with science subjects dimensions, gamification can facilitate this dimension in the fourth dimension, namely student involvement and motivation to learn. The use of gamification elements can increase student involvement and motivation. When student involvement increases, learning outcomes will also increase.

\subsection{Hypothesis Testing 2}

The data results in table 2 show that there is no significant difference in the comprehension concept between groups of students who have high achievement motivation and low achievement motivation because the value obtained is $0.822>0.05$. This data means that there are students with low motivation who can understand the concept well through gamification.

This finding is in line with Groening and Binnewies[53] research, which found no effect of motivation on learning outcomes when using gamification. Tan et al., [54] find that achievement motivation does not affect the achievement of learning outcomes. Mekler et al.,[55] also found that the use of structural gamification elements, namely points, levels, and 
leaderboard, did not significantly affect learning outcomes for students with high or low motivation.

Prensky's theory said that teaching digital native students is very effective with gamification learning settings [16]. Students who have high and low motivation are both able to understand the concept well. In addition to achievement motivation, children's learning outcomes are also influenced by family and parent factors, such as encouraging their children to excel, conveying high expectations, rewards and punishments, giving positive responses, and encouraging independence [56].

\subsection{Hypothesis Testing 3}

The results showed no interaction between gamification and achievement motivation in the comprehension concept because the value obtained was $0.358>0.05$. This finding is following the findings of Arsani et al., [57] that other factors besides moderating variables can affect learning outcomes whose learning conditions include factors in the field of study and learner factors. The character of the field of science in this study explains abstract concepts. In this study, the character of learners is students in the age range of 8-9 who can think for concrete operations who have difficulty dealing with abstract problems. Piaget [58] suggested teaching children in this age range by using real objects. At this stage, the child likes questions for which the answers are available. In some elements of gamification (Kahoot), all the answers to the questions are provided.

In addition to achievement motivation, students cognitive styles [59] and social skills [60] can be other components of student condition variables that affect learning outcomes. The research results [61] show that learning styles also influence learning outcomes of conceptual comprehension among students depending on visual, auditory, and kinesthetic learning style preferences.

\subsection{Hypothesis Testing 4}

The analysis results showed a significant difference in creative thinking skills between groups of students who used mixed gamification and content gamification because the value obtained was $0.000<0.05$. This data means that mixed gamification has a significant effect on improving creative thinking skills. The increased value of creative thinking before and after the implementation of gamification was $27 \%$ in the mixed gamification group and $22 \%$ in the content gamification group. The findings of this study are following Aljraiwi (2019) findings that gamification effectively improves the creative thinking of elementary school students. In line with this, Rahman and Ya [63] argue that gamification challenges students to think creatively and apply new ideas in solving problems.

\subsection{Hypothesis Testing 5}

The analysis results showed no significant difference in creative thinking skills between groups of students who have high achievement motivation and low achievement motivation because the value obtained is $0.512>0.05$. This data means that students with high and low motivation have the same creative thinking skills after the implementation of gamification. This finding means that motivation is not the only factor that influences creative thinking. The factors that influence a person's creativity is metacognition or thinking strategy [64], metacognitive skill [65], unique creative insights [66], and personality [67]. So it can be concluded that children's thinking strategy, creative insights, and personalities are other factors besides motivation that affects creative thinking.

In line with this research, [68] argues that three factors influence creativity, namely: metacognitive skills to process new information and use the knowledge that has been acquired; large and fluent knowledge base and mastery of skills in specific domains; and a set of attitudes, character, and motivation obtained from parents, teachers, mentors, peers, and personal experiences 
that influence individuals to seek suitable alternatives, new configurations, or unique solutions.

\subsection{Hypothesis Testing 6}

The analysis results showed no interaction between gamification and achievement motivation on creative thinking skills because the value obtained is $0.667>0.05$. This data indicates that motivation cannot be relied on by gamification in improving creative thinking skills because creativity does not only come from motivation but the initial ability and the learning environment [57]. To improve creative thinking skills, the selection of learning strategies needs to be considered because learning strategies also affect learning outcomes [69]. When viewed from the field of study, science has the characteristics of a concept that is abstract enough to be understood by elementary school-age children, so it requires an appropriate learning strategy. The mixed gamification element used as a facility to facilitate students in constructing knowledge, with high and low achievement motivation, has not contributed directly to creative thinking's learning outcomes.

Besides being influenced by initial abilities, learning environment, and learning strategies, gaining knowledge is also influenced by cognitive processes. Bruner [70] argues that there are three processes of cognition when studying a subject, namely; acquisition of new knowledge, which refers to the process of connecting new knowledge with existing knowledge, experience, and cognitive structures; transformation, namely the process of analyzing and generalizing new knowledge to suit the new task; and knowledge evaluation, namely checking the relevance and accuracy of this knowledge.

\section{CONCLUSIONS:}

Mixed gamification successfully improves the learning outcomes of creative thinking but not for comprehension concepts' learning outcomes. For students who are taught to use mixed gamification and content gamification, motivation is not a factor that directly affects the achievement of concept comprehension and creative thinking. Other factors affect the learning outcomes of concept comprehension and creative thinking, gamification design, learning conditions, initial knowledge, thinking strategies, insights, and the environment.

The research results on improving learning outcomes due to using gamification differ depending on the applications context [71]. This result shows that caution is needed in the design of gamification and the use of its elements. This study's results are impressive because the complexity in selecting and using gamification elements is not necessarily better. This is evident from classes that use gamification elements more and get more learning outcomes of conceptual comprehension, which are not too different from classes that use fewer gamification elements, namely content gamification. Carefulness in choosing gamification elements is needed because the use of gamification in class is not without risks. The successful gamification, both mixed gamification and content gamification, in improving learning outcomes in conceptual comprehension is very dependent on the gamification design itself.

\section{REFERENCES:}

[1] Badan Pusat Statistik, “2 0 l 9,” p. 581, 2019.

[2] S. Muchsini, B, "Digital Natives' Behaviours and Preferences: Pre-Service Teachers Studying Accounting," Int. J. Pedagog. Teach. Educ., vol. 2, no. 2, p. 355, 2018, doi: DOI:10.20961/ijpte.v\%vi\%i.24088.Except where otherwise noted, content on this site is licensed under aCreativeCommonsAttribution4.0Internatio nalLicense.

[3] T. A. dos Reis, "Study on the Alpha Generation and The Reflections of its Behavior in the Organizational Environment," Quest Journals J. Res. Humanit. Soc. Sci., vol. 6, no. 1, pp. 9-19, 
2018.

[4] V. Turk, "Understanding Generation Generation Alpha," London, UK, 2017.

[5] E. Jaleniauskiene and P. Juceviciene, "Reconsidering University Educational Environment for the Learners of Generation Z,"Soc. Sci., vol. 88, no. 2, pp. 38-53, 2015, doi: 10.5755/j01.ss.88.2.12737.

[6] Á. Nagy and A. Kölcsey, "Generation Alpha: Marketing or Science," Acta Technol. Dubnicae, vol. 7, no. 1, pp. 107115, 2017, doi: 10.1515/atd-2017-0007.

[7] I. W. Dasna, "Peran Dan Tantangan Pendidikan MIPA Dalam Menunjang Arah Menuju Pembangunan Berkelanjutan," in Prosiding Seminar Nasional MIPA, 2012.

[8] F. Avvisati, A. Echazarra, P. Givord, and M. Schwabe, "What 15-year-old students in Indonesia know and can do: Snapshot of performance in reading, mathematics, and science," 2019.

[9] Kemdikbud, "Kuatkan Sinergisitas, Kemendikbud Sosialisasikan Kebijakan Pada Pemangku Kepentingan.” Biro Komunikasi dan Layanan Masyarakat Kementerian Pendidikan dan Kebudayaan, Jakarta, 2019.

[10] K. Chua and M. Karpudewan, "The role of motivation and perceptions about science laboratory environment on lower secondary students ' attitude towards science," AsiaPacific Forum Sci. Learn. Teach., vol. 18, no. 2, pp. 1-16, 2017.

[11] C. H. Norlizah, "Students ' Motivation towards Science Learning and Students' $\mathrm{S}$ cience Achievement," Int. J. Acad. Res. Progress. Educ. Dev., vol. 6, no. 4, pp. 174-189, 2017, doi: 10.6007/IJARPED/v6i4/3716.

[12] N. Oktarian, "MENINGKATKAN SIKAP ILMIAH SISWA DENGAN MODEL PROJECT BASED LEARNING ( PBL ) PADA KELAS IX SMP AR-RAUDLAH JEMBER," vol. 3, pp. 7-13, 2019.

[13] P. Z. Chen, T. C. Chang, and C. L. Wu, "Effects of gamified classroom management on the divergent thinking and creative tendency of elementary students," Think. Ski. Creat., vol. 36, no. April, pp. 19, 2020, doi: 10.1016/j.tsc.2020.100664.

[14] C. Wu, J. Foos, and M. M. College, "Making Chemistry Fun to Learn," Lit. Inf. Comput. Educ. J., vol. 1, no. 1, pp. 3-7, 2010.

[15] M. Törőcsik, K. Szücs, and D. Kehl, "How generations think: Research on generation Z," Acta Univ. Sapientiae, Commun., vol. 1, pp. 23-45, 2014.

[16] M. Prensky, “Digital Natives, Digital Immigrants, Part II: Do They Really Think Differently?," On the Horizon, vol. 9, no. 6, NCB University Press, 2001.

[17] J. Hamari, J. Koivisto, and H. Sarsa, "Does gamification work? - A literature review of empirical studies on gamification," in Proceedings of the Annual Hawaii International Conference on System Sciences, 2014, pp. 3025-3034, doi: 10.1109/HICSS.2014.377.

[18] C. I. Muntean, "Raising Engagement in eLearning through Gamification," in Proceedings 6th International Conference on Virtual Learning ICVL, 2011, pp. 323329, doi: 10.1016/j.jmmm.2016.10.135.

[19] B. J. Arnold, "Gamification in Education," in American Society of Business and Behavioral Sciences (ASBBS), 2014, pp. 28-34, doi: 10.17759/jmfp.2016050302.

[20] S. Nicholson, "A Recipe of Meaningful Gamification," in Gamification in Education and Business, T. Reiners and L. C. Wood, Eds. New York: Springer, 2015, pp. 1-21.

[21] G. Richter, D. R. Raban, and S. Rafaeli, "Studying Gamification: The Effect of Rewards and Incentives on Motivation," in Gamification in Education and Business, T. Reiners and L. C. Wood, Eds. New York: Springer, 2015, pp. 22-46.

[22] K. M. Kapp, L. Blair, and R. Mesch, The Gamification of Learning and Instruction Fieldbook: Ideas into Practice. San Francisco: Wiley, 2014.

[23] [23] M. D. Hanus and J. Fox, 5148 
"Assessing the effects of gamification in the classroom: A longitudinal study on intrinsic motivation, social comparison, satisfaction, effort, and academic performance," Comput. Educ., vol. 80, pp. 152-161, 2015, doi: 10.1016/j.compedu.2014.08.019.

[24] K. M. Kapp, Gamification: Separating Fact from Fiction, no. March. Chief Learning Officer, 2014.

[25] C. Fabricatore, "Gameplay and Game Mechanics Design: A Key to Quality in Video Games," 2007.

[26] L. Sera and E. Wheeler, "Game on: The Gamification of the Pharmacy Classroom," vol. 9, pp. 155-159, 2017, doi: 10.1016/j.cptl.2016.08.046.

[27] D. Schunk, J. Meece, and P. Pintrich, Motivation in Education: Theory, Research, and Applications. USA: Perason, 2014.

[28] D. C. McClelland, J. W. Atkinson, R. A. Clark, and E. L. Lowell, The achievement motive. Oxford, England: Irvington, 1976.

[29] H. A. Murray, Expectations in Personality. New York: McGraw-Hill, 1938.

[30] M. Finogenow, "Encyclopedia of Personality and Individual Differences," Encycl. Personal. Individ. Differ., pp. 1-4, 2017, doi: 10.1007/978-3-319-28099-8.

[31] L.-H. Chiu, "Development and Validation of the School Achievement Motivation Rating Scale," Educ. Psychol. Meas., vol. 57, no. 2, pp. 292-305, 1997, doi: $10.1177 / 016344300022005001$.

[32] R. J. Marzano and J. S. Kendall, The New Taxonomy of Educational Objective, 2nd ed. California: Corwin Press, 2007.

[33] A. Kade, I. N. S. Degeng, and M. N. Ali, "Effect of jigsaw strategy and learning style to conceptual understanding on senior high school students," Int. J. Emerg. Technol. Learn., vol. 14, no. 19, pp. 4-15, 2019, doi: 10.3991/ijet.v14i19.11592.

[34] L. W. Anderson and D. R. Krathwohl, A Taxonomy for Learning, Teaching, and Assessing: A Revision of Bloom's Taxonomy of Educational Objectives. 2001.
[35] M. Surur, I. N. S. Degeng, P. Setyosari, and D. Kuswandi, "The effect of problem-based learning strategies and cognitive styles on junior high school students' problemsolving abilities," Int. J. Instr., vol. 13, no. 4, pp. 35-48, 2020, doi: 10.29333/iji.2020.1343a.

[36] M. A. Runco, Creativity Theory and Themes: Reasearch, Development, and Practice, 2nd ed. San Diego: Academic Press, 2014.

[37] M. Rusli, N. S. Degeng, P. Setyosari, and Sulton, "Peer teaching: Students teaching students to increase academic performance," Teach. Theol. Relig., no. August, pp. 1-11, 2020, doi: 10.1111/teth.12549.

[38] R. J. Sternberg, "Introduction in Creativity Research," in The International Handbook of Creativity, no. 1, J. C. Kaufman and R. J. Sternberg, Eds. Cambridge, UK: Cambridge University Press, 2006.

[39] L. Greenstein, Assessing 21st Century Skills. California: Corwin, A Sage Company, 2012.

[40] A. J. Starko, Creativity in the Classroom, 5th ed. New York: Routledge, 2014.

[41] M. Fadhli, B. Brick, P. Setyosari, S. Ulfa, and D. Kuswandi, "A Meta-Analysis of Selected Studies on the Effectiveness of Gamification Method for Children," Int. J. Instr., vol. 13, no. 1, pp. 845-854, 2020, doi: 10.29333/iji.2020.13154a.

[42] S. Kim, K. Song, B. Lockee, and J. Burton, Advances in Game-Based Learning Gamification in Learning and Education Enjoy Learning Like Gaming. Cham, Switzerland: Springer, 2018.

[43] A. Domínguez, J. Saenz-de-Navarrete, L. De-Marcos, L. Fernández-Sanz, C. Pagés, and J. J. Martínez-Herráiz, "Gamifying learning experiences: Practical implications and out- comes," Comput. Educ., pp. 380 392, 2013, doi: https://doi.org/10.1016/j.compedu.2012.12. 020.

[44] C. Mortensen and A. M. Nicholson, 
"Improved student achievement through gamification and the flipped classroom," in Conference: 2014 ADSA-ASAS-CSAS Joint Annual Meeting, 2014.

[45] F. F. Nah, Q. Zeng, V. . Telaprolu, A. . Ayyappa, and Eschenbrenner, "Gamification of Education: A Review of Literature.," in HCI in Business Lecture Notes in Computer Science, 2014.

[46] C. H. Su and C. H. Cheng, "A mobile gamification learning system for improving the learning motivation and achievements," J. Comput. Assist. Learn., vol. 31, no. 3, pp. 268-286, 2015, doi: 10.1111/jcal.12088.

[47] S. M. Fulmer and J. C. Frijters, “A review of self-report and alternative approaches in the measurement of student motivation," Educ. Psychol. Rev., vol. 21, no. 3, pp. 219-246, 2009, doi: 10.1007/s10648-0099107-x.

[48] M. D. Gall, J. P. Gall, and W. R. Borg, Educational Research: An Introduction, 8th ed. Upper Saddle River, NJ: Pearson, 2007.

[49] D. Susilowati, N. Degeng, P. Setyosari, and S. Ulfa, "Effect of collaborative problem solving assisted by advance organisers and cognitive style on learning outcomes in computer programming," World Trans. Eng. Technol. Educ., vol. 17, pp. 35-41, Jan. 2019.

[50] O. Goethe, Gamification Mindset. Switzerland: Springer, 2019.

[51] I. Fatawi, I. Nyoman Sudana Degeng, P. Setyosari, S. Ulfa, and T. Hirashima, "Effect of online-based concept map on student engagement and learning outcome," Int. J. Distance Educ. Technol., vol. 18, no. 3, pp. 42-56, 2020, doi: 10.4018/IJDET.2020070103.

[52] J. Schellinger et al., "'Doing science' in elementary school: Using digital technology to foster the development of elementary students' understandings of scientific inquiry," Eurasia J. Math. Sci. Technol. Educ., vol. 13, no. 8, pp. 46354649, 2017, doi: 10.12973/eurasia.2017.00955a.
[53] C. Groening and C. Binnewies, “"Achievement unlocked!' - The impact of digital achievements as a gamification element on motivation and performance," Comput. Human Behav., vol. 97, no. November 2018, pp. 151-166, 2019, doi: 10.1016/j.chb.2019.02.026.

[54] I. G. C. Tan, C. K. E. Lee, and S. Sharan, "Group investigation effects on achievement, motivation, and perceptions of students in Singapore," J. Educ. Res., vol. 100, no. 3, pp. 142-154, 2007, doi: 10.3200/JOER.100.3.142-154.

[55] E. D. Mekler, F. Brühlmann, A. N. Tuch, and K. Opwis, "Towards understanding the effects of individual gamification elements on intrinsic motivation and performance," Comput. Human Behav., vol. 71, pp. 525534, 2017, doi: https://doi.org/10.1016/j.chb.2015.08.048.

[56] D. Schunk, Learning Theories: An Educational Perspective, 6th ed. Boston: Pearson, 2012.

[57] I. A. Arsani, P. Setyosari, and D. Kuswandi, "Problem Based Learning Strategies Using Multiple Representations and Learning Styles to Enhance Conceptual Understandings of Chemistry," Periódico Tchê Química, vol. 17, no. 35, 2020.

[58] J. Piaget, "The theory of stages in cognitive development.," in Measurement and Piaget., New York, NY, US: McGrawHill, 1971, pp. ix, 283-ix, 283.

[59]S. Azmi, I. N. S. Degeng, W. Kamdi, P. Setyosari, and S. Wiyono, "The effect of value clarification learning strategies and social inquiry on concept comprehension and student tolerance attitudes with different cognitive style," Int. J. Civ. Eng. Technol., vol. 9, no. 11, pp. 1072-1083, 2018.

[60] F. Sukmawati, P. Setyosari, Sulton, and Purnomo, "The Effect of Project-based Collaborative Learning and Social Skills on Learning Outcomes in Biology Learning," J. Educ. Gift. Young Sci., vol. 7, no. 4, pp. 1325-1344, 2019. 
[61] S. Harmono, I. N. S. Degeng, P. Setyosari, Sulton, and Y. N. Hanief, "The use of quantum learning styles: A research design approach to improve student skills and conceptual understanding of the basic movement of football," Int. J. Innov. Creat. Chang., vol. 12, no. 8, pp. 262-278, 2020.

[62] S. Aljraiwi, "Effectiveness of gamification of web-based learning in improving academic achievement and creative thinking among primary school students," Int. J. Educ. Pract., vol. 7, no. 3, pp. 242257, 2019, doi: 10.18488/journal.61.2019.73.242.257.

[63] S. M. A. Rahman and S. Ya, "Gamified Learning to Improve Higher Order Thinking among Malaysian Students," vol. 6, no. 2, pp. 9-21, 2018.

[64] J. H. Flavell, "Metacognition and cognitive monitoring: A new area of cognitivedevelopmental inquiry.," Am. Psychol., vol. 34, no. 10, pp. 906-911, 1979, doi: 10.1037/0003-066X.34.10.906.

[65] D. D. Utami, P. Setyosari, W. Kamdi, S. Ulfa, and D. Kuswandi, "THE EFFECT OF SMART-PBL LEARNING STRATEGY AND ACADEMIC-SELF LEARNING CHEMISTRY," Periódico Tchê Química, vol. 17, no. 35, pp. 960-976, 2020.

[66] R. S. Nickerson, "Enhancing creativity.," in Handbook of creativity., New York, NY, US: Cambridge University Press, 1999, pp. 392-430.

[67] B. Hennessey and T. Amabile, "Creativity," Annu. Rev. Psychol., vol. 61, pp. 569-598, Feb. 2009, doi: 10.1146/annurev.psych.093008.100416.

[68] J. F. Feldhusen, "Creativity: R Knowledge Base, Metacognitive Skill, and PersonaIity Factors," J. Creat. Behav., vol. 29, no. 4, pp. 255-268, 1995, doi: https://doi.org/10.1002/j.21626057.1995.tb01399.x.

[69] J. Siburian, A. D. Corebima, Ibrohim, and M. Saptasari, "The correlation between critical and creative thinking skills on cognitive learning results," Eurasian J. Educ. Res., vol. 2019, no. 81, pp. 99-114, 2019, doi: 10.14689/ejer.2019.81.6.

[70] J. Bruner, Going Beyond the Information Given. New York: Norton, 1973.

[71] S. Subhash and E. A. Cudney, "Gamified learning in higher education: A systematic review of the literature," Comput. Human Behav., vol. 87, pp. 192-206, 2018, doi: 10.1016/j.chb.2018.05.028.

[72] Khan, S., Arshad, M. A., \& Khan, K. (2018). Self-Development Through Soul Management: Context of Islamic Spiritual Intelligence. Research Journal of Commerce Education \& Management Sciences, 1(1). 


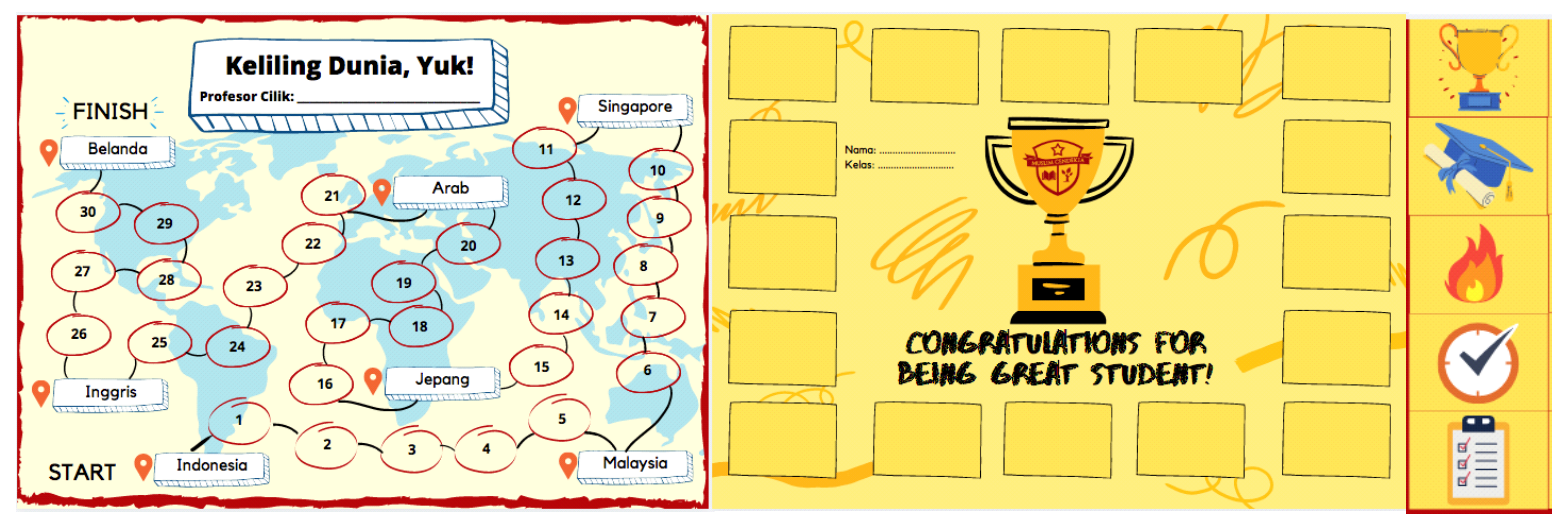

Figure 2. Element of mixed gamification for experimental class.

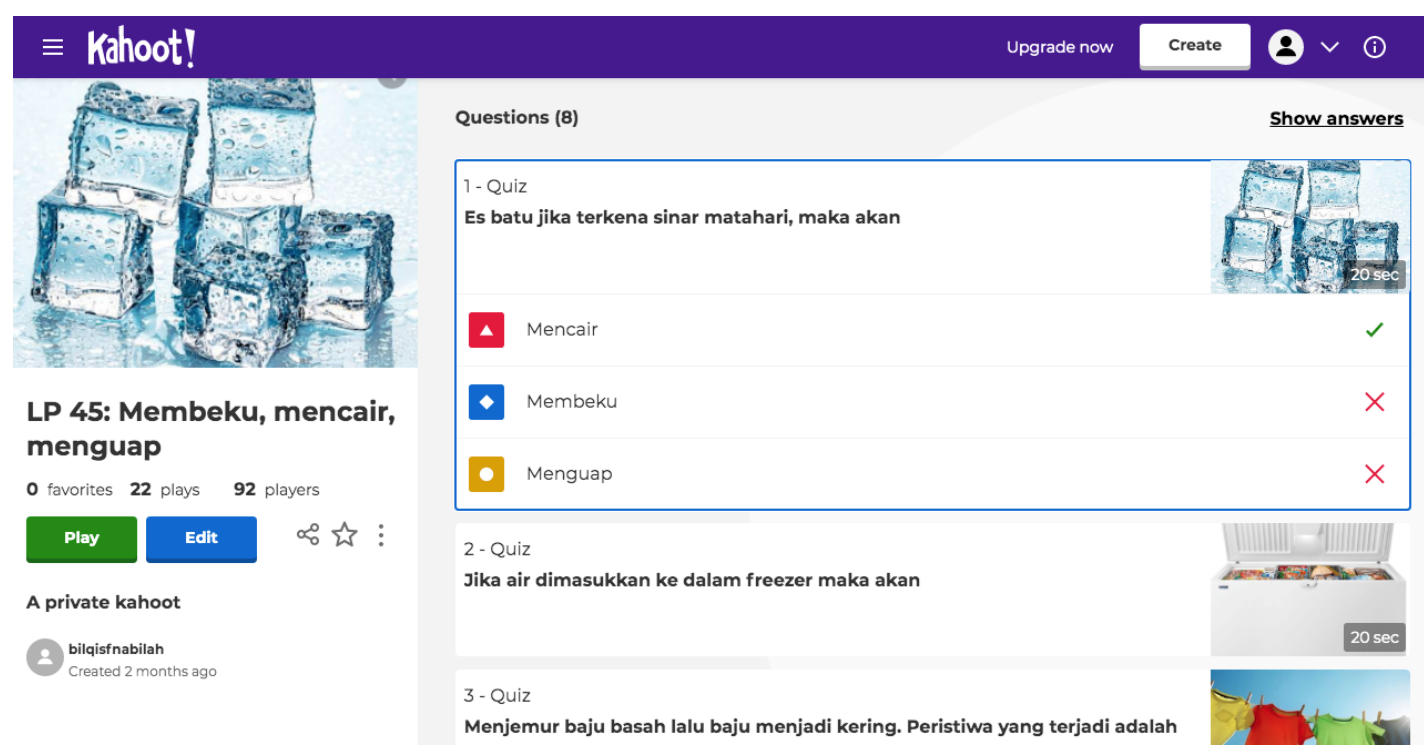

Figure 3. Element of content gamification for control class. 